\title{
Foreignization Strategy in Translating Chinese Culture-Loaded Words
}

\author{
Ling Jiang ${ }^{1}$, Yuyan Zhuang \\ School of Foreign Languages, Southwest University of Political Science and Law, Chongqing, China \\ *Corresponding Authors: Ling Jiang, School of Foreign Languages, Southwest University of Political \\ Science and Law, Chongqing, China
}

\begin{abstract}
The translation of Chinese culture-loaded words plays an important role in making Chinese culture go global. This paper investigates the foreignization strategy in translating Chinese culture-loaded words from a cultural perspective, which involve three main translation methods: transliteration, transcoding or literal translation and transliteration combined with literal translation. It is hoped to provide enlightenment to translation of Chinese culture-specific concepts and promote the spreading of Chinese culture across the world.
\end{abstract}

Keywords: Foreignization, Chinese culture-loaded words, transliteration, literal translation

\section{INTRODUCTION}

Translation as a trade or societal practice has been long-standing in China and abroad, and the approaches to dealing with the issues that are involved in the production and characterization of a translated text have also been decidedly diverse in both Chinese and Western traditions, due to the multi-dimensional properties of a translated text and the inherently cognitive process that produces the translated text. In order to push China open toward the world, Chinese language and Chinese culture play an essential important role in disseminating Chinese spirits. Chinese culture-loaded words, embodiments of conveying Chinese characteristics, are necessary tools in the global cultural communication.

This paper aims to expound on the foreignization strategy in translating Chinese culture-loaded words from a cultural perspective, and proves that proper translation of Chinese culture-loaded words is crucial for foreign readers to understand Chinese culture.

\section{Language, Culture and Translation}

Language is "a system of communication consisting of sounds, words, grammar, etc., used by humans to communicate thoughts and feelings." (Oxford Advanced Learner's English-Chinese Dictionary, 1997) As both an important integral of culture and the carrier of culture, language can describe, analyze and evaluate not only human knowledge and experience, but also customs, habits and behaviors. Also, language, as a mirror of culture, has been influenced and shaped by culture.

Translation, as a means of communication or cultural and people-to-people exchanges, plays an important role in spreading culture ever since countries and languages keep contact with each other. It is a cross-cultural language communicative activity, which is not only the process of language transformation, but also a kind of cultural transmission activity.

\section{Foreignization Strategy in Translating Chinese Culture-LoAded Words}

\subsection{Domestication and Foreignization}

One of the most striking features in contemporary translation studies is the orientation towards cultural transfer than linguistic transfer. Generally speaking, here are two principal strategies to deal with culture when translation, namely, domestication and foreignization. This paper uses two terms

\footnotetext{
$11_{*}$ This work was supported by the grant from MOE (Ministry of Education in China) of Humanities and Social Sciences [Project 18XJC740003].
} 
proposed by Lawrence Venuti, an American translation theorist, to describe two different translation strategies. In addition, the same idea that there are only two different strategies of translation was proposed by a famous German philosopher Friedrich Schleiermacher in his lecture On the Different Methods of Translation (1813). To be specific, the translator either tries his/her best to silence the author and make the reader towards him/her, or tries his/her best to silence the reader and push the author towards him/her (Venti, 1995, P.19-20).

The strategies of domestication and foreignization not only involve linguistic elements, but also involve cultural factors. Domestication is a target language-oriented translation strategy in terms of culture, which aims to reduce the strangeness of the language and culture of the original text for target readers by adopting fluent and natural styles. While foreignization is a source language-oriented translation strategy, which possesses the feature of retaining forms, contents and culture of original texts for target readers and therefore retains the foreignism (Shuttleworth\&Moria,1997, P.59; Nida, 1993).

Just like this saying, “巧妇难为无米之炊”, by using domestication strategy, a translator translates it as "Even the cleverest housewife cannot make bread without flour" ; while a translator, by using foreignization, may translate it as "Even the cleverest housewife cannot cook a meal without rice" (Cao, 2003). Obviously, as regards to this saying, the former is easier to be understood and accepted by its target readers, because foreigners often eat bread as their staple food. While the latter one aims to highlight cultural differences and disseminate the original culture by retaining images "rice" of original culture and enables target readers to taste the flavor of exoticism (Zhang, 2010, P.44).

In view of translating culture-loaded words, the purpose is to get across Chinese culture as for foreigners. In this way, for foreign readers, they need to learn what they are unfamiliar with in the source language culture reflected in Chinese culture-loaded words rather than to reinforce what is already familiar. Meanwhile, by using foreignization translation strategy, it enables the target reader to taste and enjoy the original flavor of Chinese culture, which is conductive to displaying its unique glamour of Chinese culture to the world (Pan, 2004, P.43).

In addition, there is no denying that foreignization is directly related to authenticity, which in turn represents the cultural identity of the translated text. That's to say, only by using foreignization translation strategies, can authenticity of the original Chinese culture-loaded words be presented, and thus Chinese cultural identity can be recognized and expected to "go out".

\subsection{Foreignization in Translating Chinese Culture-Loaded Words}

\subsubsection{Transliteration}

Transliteration, the most common method for translating Chinese culture-loaded words, refers to spell out words in Chinese pinyin.

For example, “阴阳于人, 不翅于父母。” (extracted from《庄子：大宗师》(Chuang-tzu: the great master)) is translated into "The relationship of yin and yang to a man is no less important than that of parents to a child." (Mair, 1994, P.59). This phrase “阴阳” is transliterated as "yinyang" without explaining to demonstrate ancient Chinese cultural characteristic ( $\mathrm{Li}, 2000$, P.43). More examples like “饺子”, which is translated as “jiaozi”; “风水” translated as “fengshui”; “人参” as “ginseng”; “功夫” as "kungfu”; “普通话” as “Putonghua”; “豆腐” as “toufu”; “太极拳” as “Taichichuan”; “粤语” as “yue”; “混沌” as “wonton”; “炒面” as “chow mein”; “吒头” as “kowtow”; “旗袍” as chipao and so on.

However, sometimes, it is difficult for target readers to understand the meaning of translated texts, let alone Chinese culture. Under this circumstance, a method, transliteration with an accompany annotation, is of significant help.

For example, “正月” is translated as “The Spring Festival ends on the fifteenth of Zheng Yue" (the first lunar month of the New Year) (Su,2007). The same is true to the five classics: 《诗经》 is the Shijing or Classic of Songs (Odes, ancient folk poem), 《尚书》 is the Shangshu or Classic of Document (or History), 《礼记》 is the Liji or Record of Ceremonies and Proper Conduct, 《易经》 is the Yijing or Classic of Changes (for divination) and 《春秋》is the Chunqiu or Spring and Autumn Annals (chronicles of Confucius' own state of Lu in Shandong), with their commentaries. 


\subsubsection{Trans-Coding or Literal Translation}

It is also named as literal translation following SL (source language) forms, with or without an accompany annotation. Literal translation, one of the methods for translating Chinese culture-loaded words, makes the target texts equivalent to the source texts with respect to form, content and function.

For example, Chinese four-character idiom '亡羊补牢 (wangyangbulao)' is translated into English as "mend the fold after sheep escaped" . By trans-coding, the SL form is trans-coding into its TL (target language) counterpart, leaving the target readers to figure out what it might mean. The translator may or may not provide an annotation if trans-coding is offered. If there is an annotation, it can be explained as 'This is a Chinese idiom depicting a man mends a faulty fold whence his sheep escaped, implying that the sooner a mistake is corrected, the better.'

Also, here are some Chinese cultural expressions, which are transferred into English by trans-coding with no notes provided. The sentence “咱们没有 “举碗齐眉” 的缘分” is translated as “We just weren't meant to 'raise the bowel to the eyebrows." Here Chinese characters “举(ju)”, “碗(wan)” and “眉(mei)” are one-to-one correspondence to “raise, bowel and eyebrows”. Say, “李先生嘆他衣锦夜行” is translated as “Li lamented that it was as unnecessary as wearing brocaded clothes at night. 三思而后行(sansierhouxing) is translated into “think thrice before you take any action”, 癞蛤蟆想吃天鹅肉(laihamaxiangchitianerou) is translated into “like a toad trying to swallow a swan”, 调虎离山(diaohulishan) is translated into "to lure the tiger away from the mountain” and 纸老虎(zhilaohu) is translated into “paper tiger”. In consideration for target language readers, all these examples clearly display their images and original cultural characteristics of Chinese language.

In addition, this paper collects 150 examples of Chinese political and ideological notions, particularly showing Chinese cultural characteristics, and their English version from a parallel bilingual corpus containing 36 Chinese government white papers and parallel English translations (from Chinese government websites). Conceptually, these notions are alien to the whole English-speaking world. About 148 instances are all trans-coding, with some of the following examples. “一带一路” (yidaiyilu) is translated as “One Belt One Road”; “丝绸之路” (sichouzhilu) is translated as “the Silk Road”; “一国两制” (yiguoliangzhi) is translated into “One country, two systems”; and “供给侧结构性改革” (gongjicejiegouxinggaige) as “supply-side structural reform” .

Still, even though literal translation is intelligible, in order to have more clear and understandable expressions, illustrations will be added behind. Namely, “四大发明” (sidafaming) is translated as "the Four Great Inventions (the compass, papermaking, gunpowder and printing)" and “井底之蛙” (jindizhiwa) is translated as “the frog living at the bottom of the well (who thought the world was a little round pool of water)" . What's more, a popular Chinese saying “三个臭皮匠，顶个诸葛亮” (sangechoupijiang, dinggezhugeliang), which is translated into "two heads are better than one" by domestication strategy, conveying its original meaning but losing its images and cultural characteristic. But if it is translated as "three cobblers with their wits combined are equal to Zhuge Liang, the master mind in old China" by combining foreignization strategy with illustration, the original meaning and Chinese culture embodied in the saying are presented in a manner that the target readers are acquainted with this Chinese legend-Zhuge Liang.

In this manner, images of Chinese culture are introduced to the target readers. Therefore, this translation method under foreignization strategy plays a significant role in pushing Chinese core values and culture to "go out" toward the world (Peng, 2008, P.123).

From above, it is safe to draw a conclusion that trans-coding with or without illustration, seems to be the most commonly used method in this particular Chinese-English translation imprinted with profound Chinese culture.

\subsubsection{Transliteration Combined with Literal Translation}

It is a translation method that combines sound and meaning. Words are translated into Chinese pinyin according to their original pronunciation and added with meaning.

Such as, 颜体 is translated as “Yan style”. Here “颜” is transliterated as “yan” according to Chinese pronunciation to show Chinese cultural characteristic and “体” is translated as "style” by literal translation. In the same way, by adopting transliteration and literal translation, 清明节 is 
translated as “Qingming festival” ; 唐诗 is translated as “Tang Poetry” ; 京剧 is translated as “Peking Opera” and 东汉 is translated as “Eastern Han Dynasty” .

By using this translation method, it not only retains the cultural characteristics of source language to a greatest extent, but also helps target readers understand the original text.

\section{CONCLuSion}

Language, as an integral part of culture, plays a significantly important function in culture. Language and culture are interdependent. In other words, where there is language, there is culture. Translation, as a basic tool for disseminating culture and exchanging ideas, is expected to promote culture and communication. Foreignization, as an important translation strategy, aims to make target readers understand and accept alien language and culture. Hence, it is apparent that by using foreignization strategy our Chinese culture manifesting itself in those culture-specific words can be revealed to its target readers in cross-cultural communication.

To conclude, conforming to the fundamental translation principle of faithfulness and functional equivalence, this paper discusses foreignization strategy in translating Chinese culture-loaded words or expressions. And it is hoped to shed some light on translation of culture-loaded concepts in traditional Chinese classics.

\section{REFERENCES}

[1] Cao Xueqin, Gao'e. (2003). A Dream of Red Mansions. Tr by Yang Hsien-yi\& Gladys Yang. Beijing: Foreign Language Press.

[2] Li Wenge. (2000). Cultural Implication and Translation of Chinese Cultural Classics. Language Study. (1): 42-44.

[3] Mair, Victor. H. (1994). Wondering on the Way. New York: Bantam Books.

[4] Nida, E. A. (1993). Language Culture and Translating. Shanghai Foreign Language Education Press.

[5] Pan Wenguo. (2004). Translating into/ out of One's Mother Tongue: On the Feasibility of Translating Chinese Classics into English by Native Chinese Translators. Chinese Translators Journal. (2): 40-43.

[6] Peng Renzhong. (2008). The Translation Strategy of Foreignization and Cross-cultural Communication. Foreign Languages Research. (4): 122-124.

[7] Shuttleworth Mark, Moria Cowie. (1997). Dictionary of Translation Studies. St. Jerome Publishing, 59.

[8] Su Shuyang. (2007). A Reader on China. New York: Better Link Press.

[9] Venuti, Lawrence. (1995). The Translator's Invisibility: A History of Translation. Routledge, 19-20.

[10] Zhang Yongping. (2010). Foreignization in Translating English and Chinese Proverbs from the Perspective of Cultural Manifestation. Journal of Lanzhou University. (1): 41-45.

\section{AUTHORS' BIOGRAPHY}

Ling Jiang, is currently an associate professor and supervisor in School of Foreign Languages of Southwest University of Political Science and Law. She got a doctorate degree in English Language and Literature at Shanghai International Studies University in 2012. She has published many papers in prestigious local and international journals and her recently published book is titled Representation and Reproduction: the Discursive Construction of Judge Identity in Courtroom Discourse. She also conducted more than 10 research projects, including national and provincial-level projects. Her main research interest is Forensic Linguistics, Legal Translation, Pragmatics, Discourse Analysis and Systemic Functional Linguistics (SFL).

Yuyan Zhuang, got a master degree in Foreign Linguistics and Applied Linguistics in School of Foreign Languages of Southwest University of Political Science and Law in 2020. She is also the author and co-author of several articles. She has conducted and participated in three important projects ranging from municipal to school-level projects.

Citation: Ling Jiang, Yuyan Zhuang. "Foreignization Strategy in Translating Chinese Culture-Loaded Words" International Journal on Studies in English Language and Literature (IJSELL), vol 8, no. 11, 2020, pp. 37-40. doi: https://doi.org/10.20431/2347-3134.0811004.

Copyright: (C) 2020 Authors. This is an open-access article distributed under the terms of the Creative Commons Attribution License, which permits unrestricted use, distribution, and reproduction in any medium, provided the original author and source are credited. 